УДК 629.3.018.2

(C) М.М. Толстушко, к.т.н., В.І. Павлюк, к.т.н., Н.О.Толстушко, к.т.н. Луцький національний технічний університет

\title{
ДІАГНОСТИКА СИСТЕМ ЕНЕРГОПОСТАЧАННЯ ТА ПУСКУ КОЛІСНИХ ТРАНСПОРТНИХ ЗАСОБІВ
}

У статті наведено міркування щзодо розробки вимірювально-реєструвального обладнання для комплексної діагностики систем енергопостачання та пуску двигунів внутрішнього згоряння колісних транспортних засобів. Дано перелік та схему функціональних зв'язків між елементами комплексу вимірювально-реєструвального обладнання.

\section{ДІАГНОСТИКА, \\ ЕЛЕКТРООБЛАДНАННЯ, \\ ДВИГУН \\ ВНУТРІШНЬОГО \\ ЗГОРЯННЯ, ВИМІРЮВАЛЬНО- РЕССТРУВАЛЬНЕ ОБЛАДНАННЯ, ЕНЕРГОПОСТАЧАННЯ}

Постановка проблеми. На сьогодні транспортні засоби містять все більше електрообладнання, вимагаючи збільшення питомої потужності систем енергопостачання та пуску. Якісна робота транспорту залежить від підтримання належного його технічного стану, а зменшення витрат на ремонт реалізується запобіганням виникнення несправностей та правильним встановленням причин для їх усунення. Значна роль у цьому відводиться діагностуванню роботи, як окремих вузлів і механізмів, так і систем та комплексів електрообладнання. Велика кількість автотракторної техніки має класичне конструкційне виконання та обладнана двигунами внутрішнього згоряння (далі - ДВЗ). За даними статистики [1] значна частка виникаючих несправностей електрообладнання автомобілів припадає на системи енергопостачання і пуску ДВЗ. На сьогодні $є$ визначеними ряд заходів 3 діагностування щодо встановлення технічного стану окремих розглянутих підсистем, вузлів та їх механізмів. Процес діагностування та випробування, як правило, не викликає особливих труднощів за наявності відповідного обладнання для проведення діагностичних, регулювальних та контрольних операцій. Функціональність таких пристроїв визначає їх вартість та доступність впровадження у навчальний процес підготовки спеціалістів відповідного напряму та кваліфікації. Тому для визначення основних параметрів та характеристик роботи певного електрообладнання виникає потреба розробки окремих модулів та комплексів визначеної складності. 
Аналіз останніх досліджень і публікацій. Джерелами електричної енергії на колісних транспортних засобах традиційно $\epsilon$ генераторні установки i акумуляторні батареї. Пуск двигуна внутрішнього згоряння здійснюється електричним стартером [2-5]. Генераторні установки, будучи основним джерелом електроенергії на транспортному засобі, мають забезпечувати живлення електрообладнання і заряджання акумуляторних батарей (далі АКБ). Найбільшого поширення у таких установках набули генератори змінного струму обладнані випрямлячем та регулятором напруги [3]. Умови стартерного пуску вказують на потребу використання свинцево-кислотних АКБ. Діагностика i випробування окремих вузлів чи пристроїв для визначення контрольних параметрів та характеристик їх роботи описана у літературних джерелах [2-5].

Варто відмітити популярність розроблення та впровадження програмних рішень для комплексної діагностики систем енергопостачання та пуску двигунів внутрішнього згоряння колісних транспортних засобів 3 використанням певного діагностичного обладнання, наприклад мотор-тестерів [2].

Інформаційно-діагностичні системи все більше впроваджуються на сучасних колісних транспортних засобах [3-5].

Мета дослідження - сформулювати основи розробки вимірювально-реєструвального обладнання для комплексної діагностики систем енергопостачання та пуску двигунів внутрішнього згоряння колісних транспортних засобів 3 можливістю подальшого його впровадження у навчальний процес для проведення лабораторних занять.

Результати дослідження. Потреба у комплексній діагностиці систем енергопостачання і пуску зумовлена їх спільною роботою (рис. 1).

Складність комплексу діагностичного обладнання визначиться потребою отримання величин, що характеризують роботу зазначених систем. Тому слід проаналізувати параметри, що підлягають дослідженню. Так основними показниками роботи генераторної установки $\epsilon$ можливість видачі струму певної величини за сталої номінальної напруги та відповідних умов роботи, у тому числі і ДВЗ (навантаження на генератор, частоти обертання, температурного стану). Перелік параметрів, що характеризують стан системи наведені на рис. 2. 


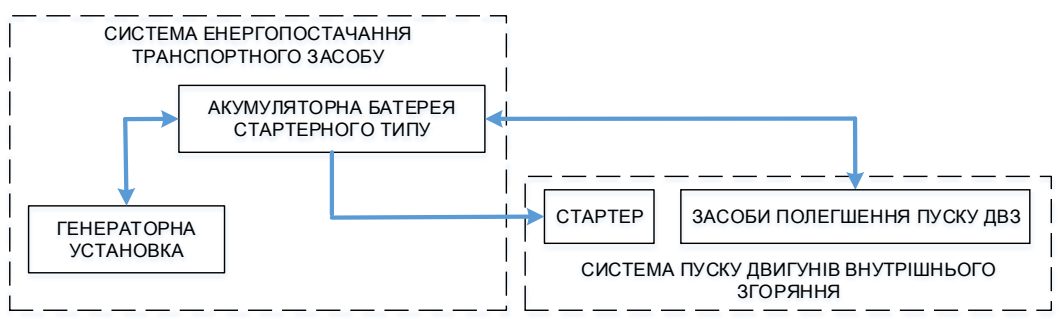

Рис. 1 - Схема взаємодії елементів систем енергопостачання і пуску ДВЗ традиційного конструкційного виконання
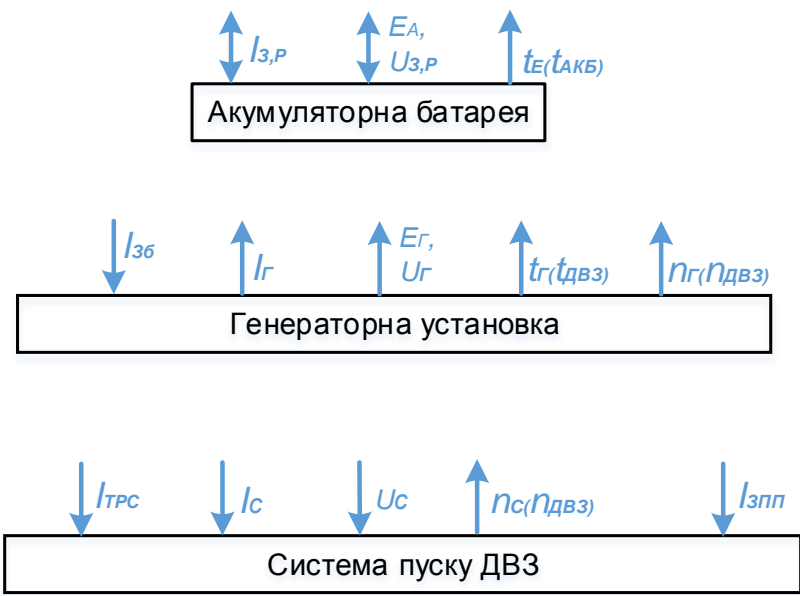

Рис. 2 - Схема параметрів, що можуть підлягати обліку для систем енергопостачання і пуску ДВЗ:

$I_{3, P}, U_{3, P}$ - струм та напруга заряду-розряду акумуляторної батареї;

$E_{A}-$ ЕРС акумуляторної батареї;

$I_{3 \sigma}-$ струм збудження генераторної установки;

$I_{\Gamma}$ - струм генераторної установки (струм навантаження);

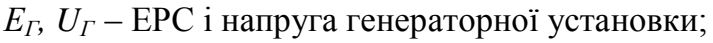

$I_{T P C}$ - струм тягового реле стартера;

$I_{C}, U_{C}-$ струм та напруга живлення електродвигуна стартера;

$I_{3 п \Pi}-$ струм живлення засобів полегшення пуску;

$n_{\Gamma}, n_{C}, n_{\text {двз }}$ - частоти обертання ротора генератора, приводної

шестірні стартера, обертання колінчатого валу ДВЗ;

$t_{\Gamma}\left(t_{\text {ДВ }}\right), t_{E}\left(t_{A K Б}\right)$ - температура генераторної установки (ДВ3), електроліту (АКБ). 
Для стартерної акумуляторної батареї необхідно проаналізувати пускові та зарядні струми, електрорушійну силу (далі - ЕРС) та напругу розряджання та заряджання за відповідної температури. Стартерний пуск двигуна внутрішнього згоряння відбудеться за умови забезпечення крутного моменту та частоти обертання на колінчастому валу ДВ3 та споживання електродвигуном стартера струму визначеної величини 3 допустимим падінням напруги у системі.

Примірний склад та функціональні зв'язки вимірювальнореєструвального обладнання для комплексної діагностики систем енергопостачання та пуску двигунів внутрішнього згоряння колісних транспортних засобів може бути представлена у вигляді схеми (рис. 3).

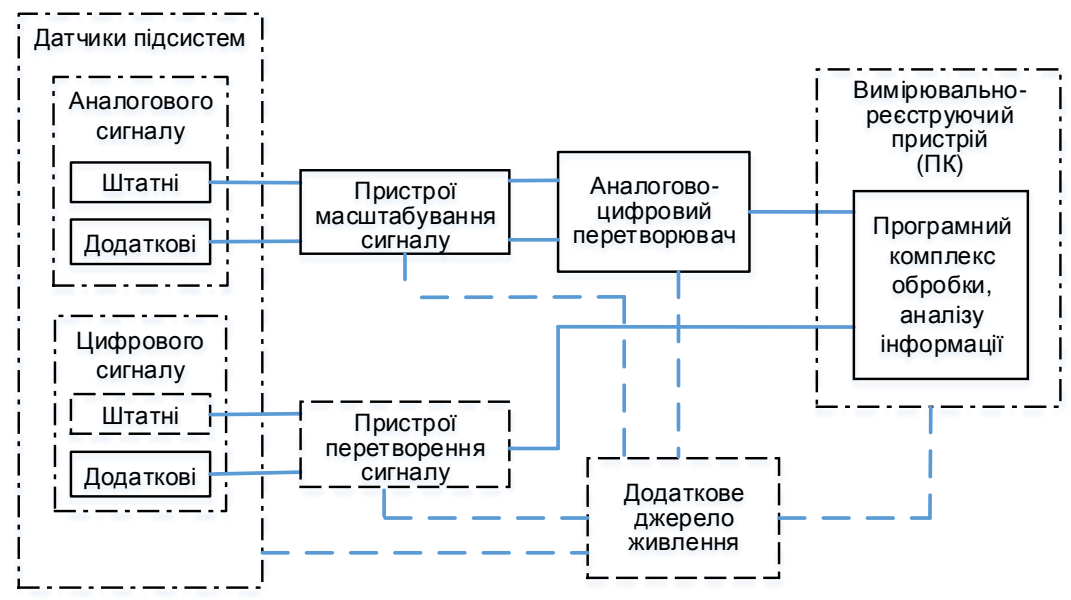

Рис. 3 - Примірний перелік та схема функціональних зв'язків між елементами комплексу вимірювально-реєструвального обладнання

Доступність використання складових запропонованого комплексу, під час комплектації необхідного набору елементів обладнання, дасть можливість впровадити розробки такого типу у навчальний процес підготовки фахівців, що спеціалізуються на діагностуванні, технічному обслуговуванні та ремонтові електрообладнання колісних транспортних засобів.

Висновки. Наведені міркування можуть бути основою для розроблення лабораторного вимірювально-реєструвального обладнання для комплексної діагностики систем енергопостачання 
та пуску двигунів внутрішнього згоряння колісних транспортних засобів.

1. Adac [Electronic resource]. - Mode of access: http://www.adac.de/. - Title from the screen.

2. Equipment for diagnosing and repair of the engine management systems [Electronic resource]. - Mode of access: http://www.injectorservice.com.ua. - Title from the screen.

3. Сажко В.А. Електрообладнання автомобілів і тракторів / Сажко В.А. - К.: Каравела, 2009. - 400 с.

4. Дентон Т. Автомобильная электроника / Том Дентон; пер. с англ. Александрова В.М. - М.: НТ Пресс, 2008. - 576 с.

5. Хернер А. Автомобильная электрика и электроника / А. Хернер,

Х.-Ю. Риль; пер. с нем. ЧМП РИА «GMМ-пресс». - М.: Издательство «За рулем», 2013. - 624 с. 